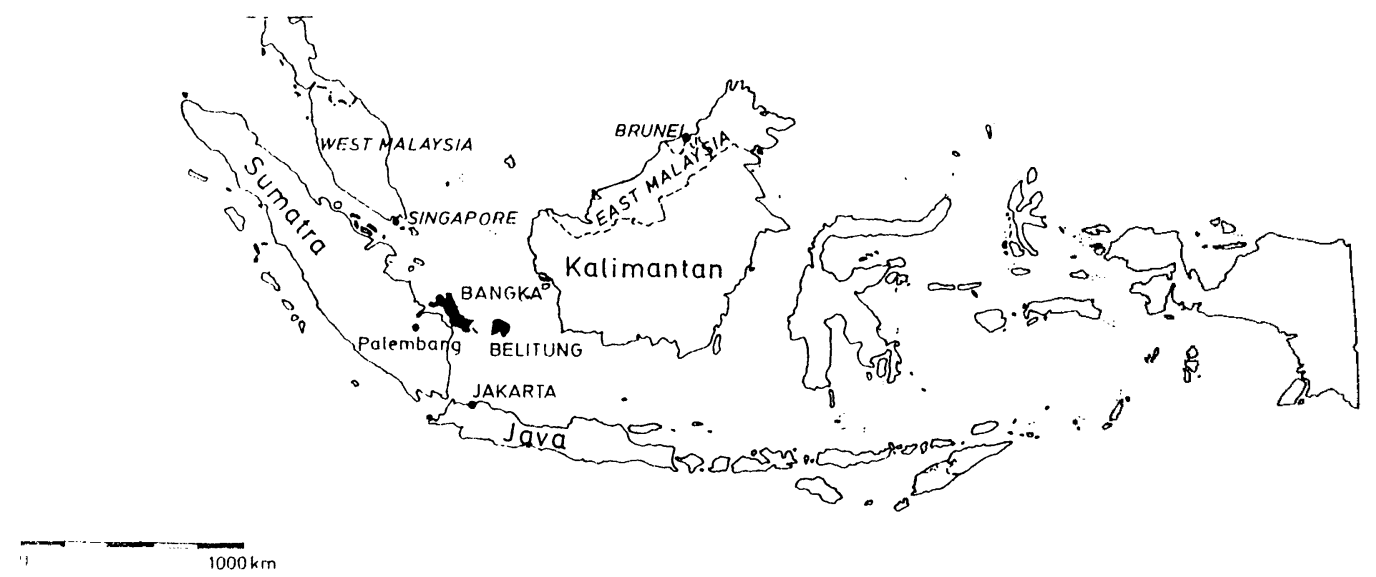

INDONESIA: Bangka and Belitung in relation to surrounding islands

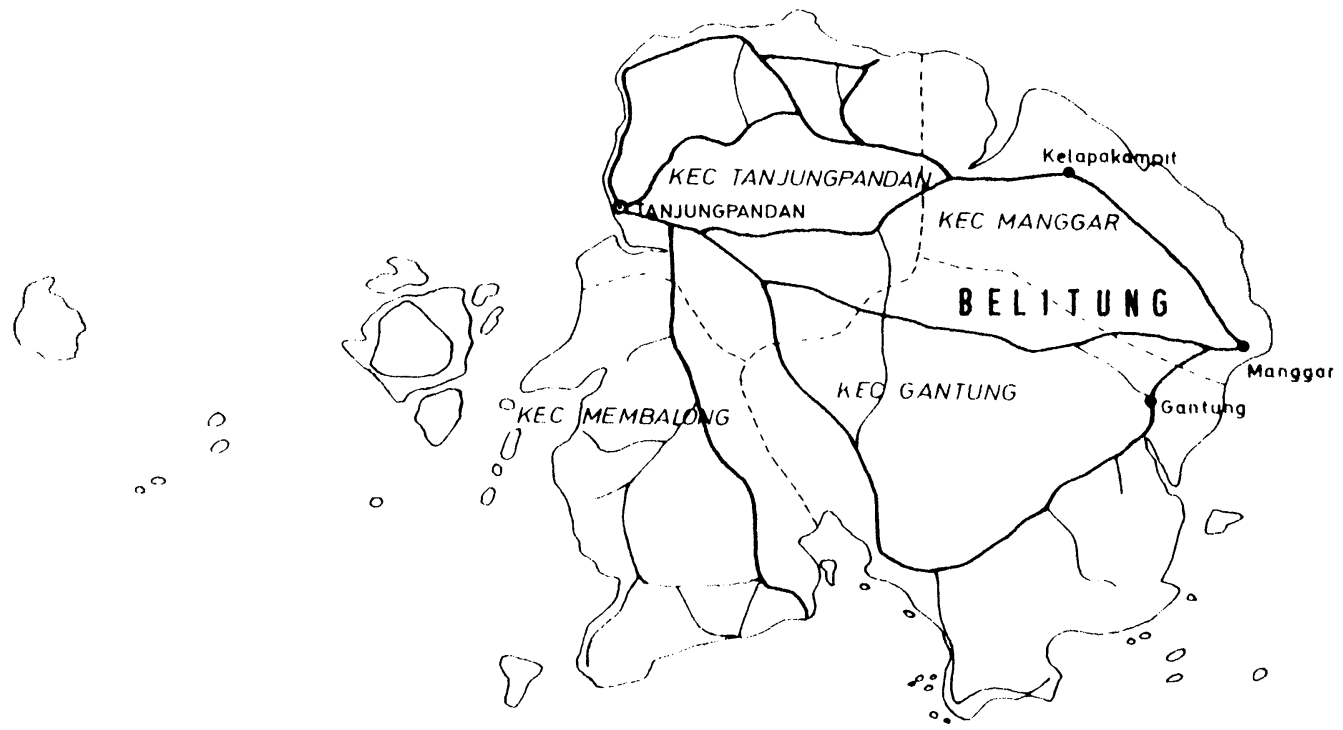

$7,5 \quad 22,530 \mathrm{~km}$ 


\title{
COMPANY IsLAND: A NOTE ON THE HISTORY OF BELITUNG
}

\author{
Mary F. Somers Heidhues
}

Indonesians automatically link the islands of Bangka and Belitung for the two neighbors are known as the center of the nation's tin mining. Whereas Bangka's production has always been a state enterprise, the Billiton Maatschappij, or Mij as it was first known, (Billiton is the Dutch pronunciation for Belitung), a single company, and its successors controlled the mines and dominated the history of Belitung for the century from its opening in 1850 until 1958, when Indonesia nationalized Netherlands' properties and dissolved the tin company.

The Billiton Mij began as a private enterprise; after 1892, five-eighths of its shares were bought by the Netherlands Indies government, and it continued as a joint enterprise until its dissolution. Elsewhere in Indonesia, kumpeni meant the Dutch East Indies Company, or VOC, but in Belitung, the maskapai so shaped the fate of the island that a comparison with U.S. "company towns" seems appropriate. ${ }^{1}$ Belitung, perhaps more than any other area of comparable size - the island is $79 \mathrm{~km}$ long and $77 \mathrm{~km}$ wide, or about $4,330 \mathrm{sq} \mathrm{km}$-in the Netherlands Indies, was a "company island."

\section{The Opening of Belitung and the Billiton Mij}

Eighteenth-century maps of the Indies ${ }^{2}$ provide only vague outlines of Belitung, and the island maintained a rather shadowy existence until the nineteenth century although it was not far from major shipping lanes. Poor charts and pirates' lairs made an approach hazardous.

\footnotetext{
This research was undertaken as part of a study of Bangka conducted in affiliation with Southeast Asia Studies, University of Passau, W. Germany, and supported by the Stiftung Volkswagenwerk. See Mary F. Somers Heidhues, Bangka Tin and Mentok Pepper: Chinese Settlement on an Indonesian Island (Singapore: Institute of Southeast Asian Studies, forthcoming). Opinions are the responsibility of the author.

${ }^{1}$ Ann Stoler chose the title "In the Company's Shadow" for her Ph.D. dissertation (Columbia University, 1983); she was writing of the four major plantation companies in East Sumatra, in particular, the Deli-Maatschappij and the Deli Planters' Association. Belitung's Company did more than cast a shadow.

2 See for example, Francois Valentyn, Oud en Nieuw Oost-Indiën (Doordrecht: Joh. van Braam, 1724). A legend explains the derivation of Belitung's name as "Bali-potong," a piece cut off from Bali. Husnial Husin Abdullah, Sejarah Perjuangan Kemerdekaan RI di Bangka Belitung (Jakarta: PT Karya Unipress, 1983), p. 208.
} 
Belitung had previously delivered a variety of iron products-byltjes (hatchets) and parangs (knives)-thousands of which arrived in Java annually in the late seventeenth century. ${ }^{3}$ Apparently, imports of European iron wares subsequently displaced local products for the trade soon disappeared. The agent (ondercoopman) of the East India Company, Jan de Harde, visited the island, as he did Bangka briefly in 1668 and 1672, but found little of commercial interest. 4 (Even in the first half of the twentieth century, the island produced little of value for export besides tin; significant products were small amounts of smallholder rubber, copra, resins, and white pepper.5)

In the eighteenth century, as tin mining appeared for the first time on Bangka, people suspected that Belitung also contained deposits. ${ }^{6}$ Natives, or perhaps immigrant Chinese, probably worked tin (which often occurs in conjunction with iron and can be handled with similar refining methods) on Belitung and for decades sold it clandestinely outside the East India Company's area of control.

In the seventeenth and eighteenth centuries, Belitung's Malay rulers, called depati and ngabehi (there were four ngabehi in the 1850s), seem to have been subordinate to Palembang, but they had important cultural ties to Java. ${ }^{7}$ During the Napoleonic Wars and the British occupation of Dutch possessions in the Indies, London laid claim to Belitung in 1812. Raffles is said to have toyed with the idea of making it a British port, but that was before Singapore was established (1819). At the insistence of Major M. H. Court, their officer in Bangka, the British retained Belitung, probably as a bargaining "chip," until the final division of British and Netherlands' territories in the region in $1824 .{ }^{8}$ Although they attempted to establish a native ruler of their choice in power, the British paid no further attention to developing the island, which, in the colonialist thinking of the time, had to belong to one European power or another. From 1824, the power was the Netherlands.

The Dutch, however, had their hands full exploiting Bangka, and they doubted that the world tin market could absorb more tin than Bangka was producing. They were, therefore, content, once their control of Belitung was acknowledged, to confirm a depati who would be subject to the Resident of Bangka as the local ruler and to assign an assistant resident named Bierschel to supervise matters. Bierschel actually found some tin, and in 1827 the Kapitan Cina (captain of Chinese) in Mentok (Bangka), Tan Hongkwee, signed a contract

\footnotetext{
${ }^{3}$ Various entries in Dagh-Register gehouden int Casteel Batavia vant passerende daer ter plaetse als over geheel Nederlandts-India, ed. J. A. van der Chijs (Batavia: Landsdrukkerij, various years) from 1668 to 1682 list the arrival of ships from Belitung, especially in Banten, with iron implements from Belitung, wax, damar (resin), and woven mats. In exchange, the ships took textiles and other products.

${ }^{4}$ F. W. Stapel, Aanvullende gegevens omtrent de geschiedenis van het eiland Billiton en het voorkomen van tin aldaar (The Hague: NV Gemeenschappelijke Mijnbouwmaatschappij Billiton, 1938), pp. 97-117 and Dagh-Registers for 1668 and 1672.

${ }^{5}$ Algemeen Rijksarchief, den Haag, Indonesië, no. 544 [hereafter cited as ARA, Rapp. Indon.].

${ }^{6}$ For example, J. C. M. Radermacher, "Beschrijving van het eiland Sumatra," Verhandelingen van het Bataviaasch Genootschap van Kunsten en Wetenschappen 3 (1781): 84, who calls it "a hill of tin, like Bangka"; or the Dutch commissioner Paravicini, cited in G. H. van Soest, "Het contract von 1755 met Palembang," Tijdschrift voor Nederlandsch-Indië 2 (1880): 183.

7 "Sedikit dari Sejarah Pulau Timah Belitung," pt. 1, Stannia 2 (January 1971): 11, and pt. 2, 2 (February 1971): 23 24.

8 Nicholas Tarling, Anglo-Dutch Rivalry in the Malay World, 1780-1824 (Cambridge: Cambridge University Press, 1962), p. 82. M. H. Court, An Exposition of the Relations of the British Government with the Sultaun and State of Palembang (London: Black, Kingsbury, Parbury and Allen, 1821), p. 207, says Belitung produced trepangs, agar-agar, birds' nests, honey, wax, damar, and a considerable amount of iron for kris. Tin found there, he thought, might have been smuggled from Bangka.
} 
with the Indies authorities to develop Belitung's mines. The Dutch soon lost interest in the island, however, and abolished the assistant resident's post, leaving only the depati in local authority. ${ }^{9}$ In midcentury, Batavia maintained only a small detachment of native troops from Java on the island's west coast, with replacements rotated from Bangka every three months. They were a symbol of Dutch authority and, possibly, a barrier to piracy in the area. ${ }^{10}$

Finally, in 1850, a Dutch mining engineer named Croockewit searched Belitung for tin for three months. Although the depati insisted that his island had no tin and that visits to certain parts of the island would be dangerous, an old man approached Croockewit's companions, claiming to know where evidence of old mines was to be found. Asked to accompany the party, the informant suddenly pleaded illness, even though the engineer had promised him safe conduct to Bangka if he revealed the secret. ${ }^{11}$ Having uncovered nothing but a deposit of "false tin" ore (which resembled tin but was not), Croockewit concluded solemnly "that the island of Belitung contains no tin ore in its soil . . . that is, not in such form as has been found and could be worked on Bangka up to now."12

The next group of explorers, led by pioneer John Loudon, came a few months later in June 1851. Their party was more numerous and better equipped physically and psychologically than Croockewit's. Loudon told the depati, who had successfully warded off Croockewit, that the government was determined to find ore. Because one man had not succeeded, six had come; if they found no tin, an even larger party would follow. Not surprisingly, the group promptly found ore ("twenty-four hours after our arrival"). They also found old, shallow diggings and, somewhat later, signs of primitive pit-and-tunnel burrowings, which the Dutch, recalling the time when the tin of Bangka belonged to the sultan of Palembang, called "Palembangse putjes." 13

Loudon and the other pioneers (among their financial backers and patrons in the Netherlands were Prince Hendrik and some members of the nobility) acquired the first concession to develop Belitung, which was granted in 1852 for forty years. Their project nearly foundered on health problems, whether of the Europeans or of the workmen; over one-third of the laborers perished annually in the first several years. Other enemies were the climate and the problem of recruitment, not to mention the stubbornness of those in the Indies and in Holland who still believed Croockewit had been right.

In 1860, the Billiton Maatschappij, a public shareholding company, took over the original concession and its debt of nearly one million guilders. Almost immediately, rich alluvial

\footnotetext{
9 Abdullah, Bangka Belitung, pp. 213-15. On dates and the contract of 1827, see A. A. de Vries, "Een contract omtrent tinexploitatie op Billiton van 1827," Indische Gids 40 (2) (1918): 1218-27; J. C. Mollema, De ontwikkeling van het eiland Billiton en van de Billiton-Maatschappij, 2d ed. (The Hague: Nijhoff, 1922), pp. 20-21; Corn. de Groot, Herinneringen aan Blitong, historisch, lithologisch, mineralogisch, geographisch, geologisch en mijnbouwkundig (The Hague: H. L. Smits, 1887), pp. 67-73.

${ }^{10}$ H. M. Lange, Het eiland Banka en zijne aangelegenheden ('s-Hertogenbosch: Gebr. Mulle, 1850), p. 27.

11 J. H. Croockewit, Banka, Malakka, Billiton (The Hague: Fuhri, 1852), pp. 115-16; R. van Eck, "Het Eiland Blitong," Indische Gids 5 (1) (1883): 305-24.

12 Croockewit, Banka, Malakka, Billiton, p. 41.

13 John F. Loudon, "De eerste jaren der Billiton-onderneming," IG 5 (2) (1883): 694-698. The quotation, from Loudon's diary, is on p. 696 (my translation). Loudon's father was British but had taken Dutch citizenship. The party was extremely suspicious of the depati. When he offered them a meal in which he himself refused to take part, they feared poisoning. The depati explained to an unbelieving Loudon that custom forbade his eating before sundown. If the date (June 27,1851 ) given by Loudon is correct, the depati may indeed have been up to something. According to the Regeringsalmanak, the month of fasting began on June 30 that year.
} 
deposits on the east coast of the island came to light that more than justified the efforts of Belitung's pioneers. ${ }^{14}$ Private investment had found an encouraging outlet in Belitung.

Authorities in Bangka looked jealously at the development of the smaller island. Although the tin market was expanding, they now feared that new mines would compete for a resource in short supply on Bangka-cheap Chinese coolie labor. The Resident of Bangka, responsible for the state-run mines there, forbade the Belitung group to hire coolies from Bangka and was generally meddlesome.

Consequently, Belitung again acquired an assistant resident in 1853; unlike other assistant residents in the Indies however, he was not responsible to the Resident (of Bangka) but directly to Batavia. ${ }^{15}$ This arrangement made the Company more independent of the colonial administration for the assistant resident was really in a weak position. As early as 1861, there were serious differences between the representatives of the Company and those of the colonial administration. ${ }^{16}$ From 1853 to 1932, when the island became part of the Residency of Bangka again, Belitung had thirty-two assistant residents; their term of office averaged less than 2.5 years. ${ }^{17}$ The comparatively rapid turnover would have prevented them from interfering with the activities of the mining company. Finally, police power over the island, all of which was leased to the Billiton Mij, was in the hands of the Company until 1893, when it was passed to the assistant resident. ${ }^{18}$

\section{Organization and Control of Labor}

But if the control of mining-private and not state-run-developed differently on Belitung than on Bangka, the method of working the deposits had to be imported from there. From Bangka, for example, Loudon brought in Chinese-style chain pumps to remove water from his trial diggings. ${ }^{19}$ By far the most important "import" from Bangka, however, was the kongsi, a Chinese term (Pinyin, gongsi) that means a cooperative undertaking, for example, in business, shipping, or in this case, mining. Once they had confirmed the presence of tin deposits, the pioneers acquired sixty Chinese laborers from Singapore and ordered them to organize kongsi at the mining sites. These kongsi were to organize, discipline, and pay the workers and to handle dealings with the Company, such as mining concessions and advances of food and money for the laborers.

In contrast to the kongsi of the eighteenth century in Chinese-run mines in Bangka and West Kalimantan, which were probably formed by workers who had bonds of kinship or

14 De Groot, Herinneringen aan Blitong, pp. 79-82; Mollema, Ontwikkeling, pp. 22-24. For a complete account of the history of the development of tin on Belitung from the Company's point of view, see Gedenkboek Billiton, 18521927, 2 vols. (The Hague: Nijhoff, 1927); A. F. Kamp, De standvastige tinnen soldat: 1860-1960 N.V. Billiton Maatschappij (The Hague: Billiton Mij, 1960), pp. 60-61; 275-77.

15 Mollema, Ontwikkeling, p. 33. In 1933, Belitung was subordinated to Bangka as an "Onderafdeeling" in the residency, probably in order to cut administrative costs.

16 Gedenkboek 1927 1: 19. The dispute was so serious that it provoked a decision of the governor-general that employees of the Company were not to offend the assistant resident or to demean him in the eyes of others, which seems to show that they did just that. An informant said, "They did not like each other."

17 Based on entries in the Regeringsalmanak, various years and on Mollema, Ontwikkeling, app. 2. Bangka in the same period had only twenty-two residents, with an average term of 3.6 years. In contrast to assistant residents on Belitung, most of whom had just come to the island, many of the Residents had already been in service on Bangka (or in one case on Belitung) in subordinate posts.

18 Koloniaal Verslag, 1893, 260.

19 Loudon, "Eerste Jaren," pp. 697, 703. The pump was turned not by an overshot water wheel but by manpower through a treadwheel. 
common origin, these kongsi were cooperative alliances of complete strangers, many of them pressed into service in the back alleys of Singapore. Unlike the earlier kongsi, in which all laborers held shares, there was little emphasis on equality of shareholding in Belitung. In fact, kongsi shareholders were a tiny minority of the members and at first included even European employees of the mine company. ${ }^{20}$ On Belitung, the kongsi was an expedient of the Company. The kongsi received advances and concessions from the Company, repaying them at the end of the year by delivering tin for a fixed price. After it paid off laborers who were not shareholders and other costs, the kongsi divided the remaining profits among its members. However, in the twentieth century, the idea of common risk taking by the laborers reappeared in the numpang system, to be discussed later.

\section{Changes in Belitung's Society}

The introduction of mining meant more than increased colonial control: by importing Chinese laborers, the Company changed the ethnic composition of the island.

For the majority of the population, whom outsiders called orang darat or orang gunung, the land- or mountain-dwellers, colonization brought an important change. Their isolated settlements of extended families, connected only by footpaths, gave way in the nineteenth century to villages along major roads, permitting greater control of the population and more efficient mobilization for corvée tasks. ${ }^{21}$ Furthermore, the weakness of indigenous leadership removed a potential rival to the Company. The depati Loudon had dealt with died in 1854 , his last descendant in 1873. Finally, in 1921, a demang was appointed as the highest native official; he was not necessarily from the local nobility. ${ }^{22}$

Only in auxiliary tasks as, for example, prospectors, forest workers, or policemen did Belitung's native population participate in tin mining during the colonial period. All miners were Chinese; there was no interest in hiring natives. Outside Java, in the nineteenth century, imported Chinese labor seemed to be indispensable, whether for state enterprise, as on Bangka, or for private investments, as in East Sumatra. Except for a few Indies-born peranakan Chinese, most of whom were from Bangka, workers in Belitung were mostly China-born $\mathrm{Hakka}^{23}$ brought from the four major South China ports of embarkation: Hongkong, Canton (Guangzhou), Amoy (Xiamen), and Swatow (Shantou) via Singapore. By 1865, there were over two thousand on the island; seven years later, over four thousand labored in the mines. ${ }^{24}$ In the nineteenth century, coolies were imported by a small number of local Chi-

\footnotetext{
20 Ibid., pp. 730-31, "So-called kongsi were formed with a single former mineworker as head of the mine. ... In another mine the shareholders, on paper, were Van Tuyll, Van Haeften and Den Dekker [all three were part of the original group of pioneers, together with Loudon]. . . . Later the shares were taken over by Chinese." [Emphasis in original.] The participation of Europeans was, however, an exception; it was part of mining lore that only Chinese could supervise Chinese laborers.

21 This system had been introduced in Bangka after the Amir Rebellion. See Mary F. Somers Heidhues, "From Orang Gunung to Orang Bangka," in Regions and Regional Developments in the Malay-Indonesian World, ed. B. Dahm (Wiesbaden: O. Harrassowitz, forthcoming).

22 Mollema, Ontwikkeling, pp. 25-26.

23 Hakka (Pinyin, kejia) means "guest people," so-called because they were early migrants from the north into southern Chinese provinces, above all, Guangdong.

24 L.H.W. van Sandick, Chineezen buiten China: Hunne beteekenis voor de ontwikkeling van Zuid-Oost-Azië, speciaal van Nederlandsch-Indië (The Hague: M. van der Beek's Hofboekhandel, 1909), table p. 368.
} 
nese businessmen under contract to the Company. Other attempts to meet the need for coolies in these years failed. ${ }^{25}$

With an eye to meeting its labor needs by encouraging permanent settlements, in 1864, the Company engaged in a bizarre experiment to obtain more women, bringing in some 137 Javanese from Batavia and Semarang to "marry" Chinese coolies thought capable of supporting them. Only a few of the women returned to Java; the rest formed partnerships as planned. The attempt to provide a basis for a settled population had almost no effect. As a result of the project, five years later more than one hundred women had given birth to only twenty-six children, eleven of them males. With that, the Company withdrew from the bride market; it did not record the fate of the women. ${ }^{26}$ In any case, most miners could not afford to maintain a family.

One element of the indigenous population, the small groups of boat-dwelling orang sekak, soon found a new field of activity policing the coastal waters against pirates (although some of them were pirates themselves) and transporting tin ore in their boats. ${ }^{27}$ Subsequently, they tended to settle on land and in the twentieth century have come under Islamic influence.

Precolonial (i.e., pre-1850) Belitung probably had a small number of Malay traders dwelling in trading settlements near the coast. Most doubtless had come from Sumatra, Riau, and the area around Pontianak; a few other traders were ethnic Chinese. After the arrival of the coolies, the number of Chinese traders increased; some were Hakka, like the majority of the miners, but many were Hokkien Chinese from the hinterland of Xiamen, Fujian Province, who were the majority group on Java and strongly concentrated in trade in natural products in both Java and Singapore-Malaya. ${ }^{28}$

\section{Mining Organization and Methods}

When in 1860 the Billiton Mij took over the concession, tin production still depended on Chinese labor, organization, and technology. Europeans controlled only finances, tin sales, and the leasing of the sites to the kongsi, who managed and administered the mining sites.

Soon, however, a number of technical innovations-prospecting drills, pumps, better smelting ovens and means of transportation-gave European technology a clear edge in production. Chinese laborers remained to do the heavy work. To retain something of the idea of cooperative labor and shared profits that was implicit in the original meaning of the kongsi, after 1878 the Billiton Mij organized kongsi laborers into teams called numpang that worked cooperatively and divided profits equally among their members. ${ }^{29}$

A typical Belitung kongsi thereafter consisted of perhaps four or five shareholders chosen by the Company. Many were former miners with reputations for loyalty. These share-

\footnotetext{
25 See, for example, one administrator's attempts to hire laborers from West Kalimantan and Bogor reported in Reynst and Vinju, Mededeelingen en verrigtingen in Indië (Batavia: Van Dorp, ca. 1864), pp. 74-78. The administrator, Van der Hucht, is the target of this pamphlet's criticism.

${ }^{26}$ De Groot, Herinneringen aan Blitong, pp. 356-58.

$27 \mathrm{~J}$. Groothoff, Overzicht van de tinexploitatie op het eiland Billiton (n.p., 1893), p. 97.

${ }^{28}$ Belitung still has a separate cemetery for Hokkien, as well as one for Hakka and other people from Guangdong province. See Wolfgang Franke, Chinese Epigraphic Materials in Indonesia, vol. 1, Sumatra (Singapore: South Seas Society, 1988), pp. 512-27.

29 ARA MR (Mailrapport) 27411918 C1, 3. The word numpang, according to John M. Echols and Hassan Shadily, An Indonesian-English Dictionary, 3d ed., comes from tumpang, to join with others; cf. menumpang, to ride in, stay with.
} 
holders nominated the mine head and a Company official approved him. The mine head ran the mine in all its technical and commercial aspects. A kongsi also needed a secretary or bookkeeper for maintaining its accounts with the Company (for cash and other advances and credits for sales of tin), with the numpang (for wages and for loans to the miners), and with the smelters. ${ }^{30}$ These two received a salary from the kongsi.

Kongsi shareholders could, as in Bangka, work themselves or pay a coolie to work. In the early days of the kongsi system, the custom of a shareholder hiring a coolie to do his share of work had been used to get financial support from wealthy Chinese. Sometimes the Company awarded kongsi shares to natives who had, for example, helped locate a promising mining site; they were not expected to perform any labor. Nonlaborers might also purchase or inherit shares in a kongsi, but Company policy on this changed about the time the numpang were formed. Except in the case of a dependent heir unable to work, the Company then did its best to prevent kongsi shares from falling into the hands of persons who were not working miners. ${ }^{31}$

The kongsi had one or more teams of workers, numpang, assigned to work individual sites within its concession. Numpang workers' wages depended on the amount of ore delivered by their numpang to the Company; workers shared the profits. To ensure the working of poorer sites where less ore would be obtained in spite of sincere efforts, the Company guaranteed the laborer who had otherwise worked satisfactorily a minimum annual wage of about 240 guilders, leaving the European mine administrator to judge whether poor results were due to poor terrain or to laziness. For laziness, wages were docked. ${ }^{32}$

The kongsi, for its part, supplied staple food (advanced and partly subsidized by the Company) and equipment to its numpang. Usually, the largest numpang, the numpangkongsi with the mine head as its boss, lived in kongsi headquarters. The typical buildings in the compound included living quarters, a storehouse, and a prayer house (tepekong, or in Java, toapekong, from Pinyin, dabogong, the name of the god who brought prosperity), all built around an open rectangular yard. Other numpang built living quarters near their worksites. The numpang head not only kept track of work done and advances paid to laborers from the kongsi, he also purchased and sold such goods as opium, tobacco, tea, supplementary food and religious supplies, which were usually offered to the miners on credit. 33 Shares in numpang profits depended on the number of work norms met (amounts of ore and soil actually dug and carried); and again, a careful accounting was made. Most of the risk was borne by the workers themselves. Debts to the Company and wages of the

${ }^{30}$ In the twentieth century, Belitung's ore began to be smelted off the island, first in Singapore and, after 1933, in Arnhem. A central smelter in operation on the island after 1910 closed in 1921. At present, alluvial tin is smelted in Bangka and primary tin ore in Malaysia. A. Groothoff, De Tinfusie in Nederlandsch-Indië (The Hague: M. Nijhoff, 1937),p. 12; G. C. Allen and A. G. Donnithorne, Western Enterprise in Indonesia and Malaya (London: G. Allen and Unwin, 1957), pp. 160-61; Kamp, Tinnen soldat, pp. 175-76; personal interview, Belitung, 1987.

31 This and the following paragraphs are based on the detailed report on labor organization in Belitung by the then Officer for Chinese Affairs de Kat Angelino, ARA MR $27411918 \mathrm{C}$. The numpang system was subsequently adopted in Bangka, as a result of the widespread feeling in the administration that Belitung's workers were happier and better treated than those on Bangka. See also Gedenkboek 1927, vol. 2, chap. 5, and Groothoff, Overzicht tinexploitatie, pp. 100-16. By the same token, a shareholder who went to China for more than six months had to give up his share. On the other hand, mine foremen or secretaries might receive shares in good kongsi, if the shareholders had to return them to the Company.

32 This system of determining wages was called quantumstelsel.

33 Groothoff, Overzicht tinexploitatie, pp. 110-12. In the twentieth century, the Company began to control such sales more closely, because the prices were often excessive, and the workers fell easily into debt to the numpang head. 
numpang were settled before kongsi shareholders received any profit. ${ }^{34}$ The Company risked a loss either through bad debts owed by kongsi that failed to deliver enough ore to reimburse the advances for food, supplies, and building costs or, conceivably, from a drastic fall in world tin prices. On the other hand, profits from high tin prices went to the Company because the purchase price for ore was fixed.

The Billiton Mij was exceedingly proud of this system because it meant, according to the Company, that the laborers were free men. No cash advances were paid at the beginning of the year to bind the man to the numpang (as in Bangka and East Sumatra). There, workers from the mines or plantations received cash advances on their wages and so-called reengagement premiums at the beginning of the year. Then, gambling, prostitution, and other activities might well cause them to lose the money just received. As a result, they labored for another year or more in a hopeless situation just to work off their indebtedness for the advances and premiums. ${ }^{35}$

On Belitung each year, workers decided which numpang they wished to join. This meant, according to the Company, that there was no need for the hated penal sanction in effect in East Sumatra and Bangka, which punished deserters from the plantations and mines as criminals. Miners were paid at the end of the year (originally at Chinese New Year); then they were free to remain, to choose another numpang in a better location, or, if they were free of debt, to return to China at the Company's expense. Those who had worked at least three years could apply for release from the Company to settle in one of the Chinese kampung on the island, but they were not forced to join a numpang if they remained in mine work. The Company could, however, send "undesirables" back to China at any time. ${ }^{36}$

Colonial officials were convinced that the numpang system was conducive to coolie welfare. Belitung's coolies do seem to have been better off than Bangka's (where there were no numpang until later) if, for example, we compare desertion, death, and sickness rates. Belitung had hospitals for the miners earlier than did Bangka (Bangka's reputation was so bad by the beginning of the twentieth century that coolies mutinied rather than go ashore). A colonial official, Hoetink, in 1903 praised conditions in Belitung as much as he damned them on Bangka:

For someone with sympathy for Chinese, a visit to the Billiton tin company is genuinely refreshing. Whereas elsewhere, Chinese coolies are often pictured as bestialized, as animals, scum and refuse, here not only are their strength and diligence valued, but their other good qualities are not overlooked.... The distance between masters and servants is not so great as elsewhere; coolies are not looked down on but met with kindness. ... I

34 ARA MR 2741 1918; Groothoff, Overzicht tinexploitatie, p. 119.

35 On East Sumatra's tobacco plantations, "labor contracts were usually renewed en masse after the harvest. . . gambling was informally licensed. .. ; foremen were given large cash sums. . . to dispense as 'unlimited' credit." These and other tactics forced the coolies to sign on for a new, three-year term. See Ann L. Stoler, Capitalism and Confrontation in Sumatra's Plantation Belt, 1870-1979 (New Haven: Yale University Press, 1985), p. 34. An excellent account of early plantation conditions is Jan Breman, Koelies, planters en koloniale politiek: Het arbeidsregime op de grootlandbouwondernemingen aan Sumatra's Oostkust in het begin van de twintigste eeuw (Doordrecht: Foris, 1987). For a comparison of wage payments and labor conditions on Belitung with those on Bangka, see Heidues, Bangka Tin and Mentok Pepper, especially chap. 6.

36 ARA MR 2741 1918, 14, "free labor and free emigration"; Groothoff, Overzicht tinexploitatie, pp. 105-9. The mine regulation of 1896 , however, penalized deserters who were in debt, almost making it a "penal sanction." Cf. Kamp, Tinnen soldat, pp. 97-99. 
left Billiton with the impression that nowhere could a Chinese miner have it more to his liking. ${ }^{37}$

Not all laborers on Belitung enjoyed the supposed benefits of the numpang system. The newly arrived laborers, called sinkeh or sinhak (Pinyin, xinke, new guest) were always indebted to the Company, not free to choose a numpang, and bound to stay in the mines for three years. Little job security was available to casual laborers, or to the sizable minority of coolies who worked for "private delivery" mines, small Chinese-run operations not subject to the Company's supervision. They were not members of a numpang and their living conditions were, in general, poorer than those of numpang coolies. Not surprisingly workers in these two categories always showed the highest rates of opium addiction and illnesses. ${ }^{38}$ Coolie welfare was not universal on Belitung.

What is more, two other factors limited the supposed freedom of numpang coolies: indebtedness and lack of savings. Purchases at the numpang store or on the free market for nonessential food, tobacco, tea, and opium, and debts contracted for gambling and prostitution may have left the worker in debt at the end of the year, unable to leave the numpang. Lack of savings would also have made him stay on for additional years' duty because he could not disappoint his family in China by returning without a nest egg. ${ }^{39}$

Technological change reduced the importance of numpang. Most of Belitung's deposits were alluvial or secondary and mined in open pits. There, numpang did the digging and lifting on a profit-sharing basis until unskilled labor was replaced by machines. In the twentieth century, mines began to be run directly by the mine company itself; workers were often paid hourly wages. This was the case in the underground mines where primary ore was mined. In other highly mechanized installations, such as on floating dredges, laborers also worked directly for the Company without the intervention of kongsi and numpang.

In 1921 and 1922, the number of mineworkers peaked at over twenty thousand, dropping subsequently as mechanization and lower tin prices forced cutbacks. About half of these worked in the open-pit alluvial deposits (and were, presumably, in numpang). The rest worked in various kinds of skilled or unskilled tasks; about eleven hundred labored in the primary underground mines. ${ }^{40} \mathrm{With}$ few exceptions, these workers were ethnic Chinese, most of them temporarily employed immigrants.

\section{Recruitment}

Until 1908, Singapore was the main recruiting center for Belitung's coolies. Thereafter, they came from Hongkong, recruited annually by hakteeuw (Pinyin, ketou, chief of the guests, i.e., the coolies) who received a small premium per coolie from the Company. Hongkong officials supervised recruitment, or "assisted emigration," as it was called, because the coolie himself could not normally pay his fare.

\footnotetext{
37 Cited in Kamp, Tinnen soldat, pp. 95-96 (my translation). Hoetink, at the time officer for Chinese affairs, had experience in coolie affairs in Deli's plantations as well as on Bangka. He later became the first head of the Labor Inspectorate for plantations and mines; however, based on Hoetink's activities in East Sumatra, Breman in Koelies, planters en koloniale politiek, for example, p. 209, considers him very proemployer. Nevertheless, in his reports on conditions in Bangka, Hoetink is caustic about the bad treatment of coolies there.

38 Gedenkboek 1927 2: 56.

${ }^{39}$ Chang Xizhi [Pseud.l, Wulidong huagong shiji (An account of Chinese laborers in Belitung) (Jakarta: Feicui Wenhua Jijinhui, 1963) gives the coolies' side of the story; see pp. 9-14.

${ }^{40}$ Gedenkboek 1927 1: app. 5; Mollema, Ontwikkeling, pp. 151-52.
} 
Usually, the hakteeuw also engaged in some trade and carried letters and remittances. Often he was himself a former coolie (experienced coolies were called laukeh or lohak, in Pinyin, lauke, old guest) who recruited in his home territory in China. In 1918, there were about 150 recruiters and remittance agents (suihak, in Pinyin, shuike, water- or seaborne guest) on the island. ${ }^{41}$ These men maintained contact with families in China, further evidence of the importance of regular travel between Guangdong and Belitung.

Sinkeh signed a contract to remain in the mines for three consecutive years, as noted. New arrivals received identity cards with names in Chinese and Latin characters and were assigned and sent to a mine. From the second year on, they could work for fixed wages or as members of a numpang. ${ }^{42}$

More interesting than the technical details, however, is the fact that the great majority of workers were Hakka from Meixian in Guangdong province. The area is known for its tradition of sending immigrants to Southeast Asia and, apparently, the Company's system favored recruitment in the area. Mollema estimated in 1922 that 50 percent of the workers were from Meixian and most of the rest from the neighboring districts of Huizhou and Chaozhou in the same province, where some Hakka families also had settled. ${ }^{43}$

This system was one of rapid turnover and replenishment. The Company believed that the ability of coolies to return to China with a small nest egg was an incentive for others to emigrate. The fact that recruitment took place within a comparatively small area suggests that, although work in the mines was unquestionably grueling, the chance of earning some cash (as well as the need to do so) was a positive incentive. Many workers engaged in circular migration, returning to the island after a time in China. ${ }^{44}$

Not surprisingly, workers almost never brought their wives. ${ }^{45}$ Although the Company made abortive attempts to establish a settled mining population, recruitment from China was always necessary. In spite of fluctuations (no immigrants arrived in Belitung in 1915, 1922, and 1924), 46 arrivals in other years made up for deficiencies, and immigration as a whole was sufficient for Company needs. ${ }^{47}$

\section{Financial Problems and Reorganization}

In the end, private investment did not triumph on Belitung. In 1892, the Company's first forty-year lease expired, and the state in the new concession increased its share of ownership and profits to five-eighths. From 1875 to 1891, Belitung's production climbed to match or even surpass that of Bangka, although Belitung had less than half as much territory as

41 ARA MR 2741 1918, p. 10.

42 Mollema, Ontwikkeling, pp. 155-56. Cf. Gedenkboek 1927 2: 61-62.

43 Mollema, Ontwikkeling, p. 151. For an account by a descendant of Belitung Hakka of her return visit to Meixian in the 1980s, see Myra Oyong, "Mencari Rumah Nenek Moyang di RRC," Intisari 234 (January 1983): 5-9, $139-47$.

44 The situation on Bangka was different. Recruiters for the government mines there were forced to extend their recruitment efforts in China to even more remote areas. Hakka, who were the first miners there, avoided migrating to Bangka after the late nineteenth century.

45 This assertion contradicts Oyong, "Mencari Rumah," p. 8, who writes that Hakka did emigrate with their wives. Although that may be true of those who settled as agriculturalists and businessmen, on Belitung there was little use for married women. The Company never succeeded in forming a settled Chinese mining population. Regular recruitment of men from Meixian was the best it could do, and that proved satisfactory in the end.

46 W. L. Cator, The Economic Position of the Chinese in the Netherlands Indies (Oxford: Blackwell, 1936), p. 187.

47 ARA MR 2741 1918, pp. 8-10; Gedenkboek 1927 2: 61, "Arrivals were always sufficient, but irregular." 
Bangka. Production per man was also higher on Belitung than on Bangka at that time. ${ }^{48}$ The Company, with its auxiliary activities, turned over some f750,000 from taxes, profits, and other sources to the colonial treasury annually in the decade before the increase of the state's share from one-tenth to five-eighths. ${ }^{49}$ Its initial capital, in 1860, had been only f5,000,000.50 In other aspects, the 1892 concession renewal and change of ownership made little difference in the mines themselves.

A more significant reorganization took place on January 1, 1924, when mining operations on Belitung were conceded to a joint public-private enterprise, the Billiton Joint Mining Company (NV Gemeenschappelijke Mijnbouwmaatschappij Billiton, [GMB]), established with a twenty-five year concession. Five-eighths interest was held by the government of the Netherlands Indies; three-eighths by the Billiton Mij. Although the private share of capital was reduced, the influence of the Company on Belitung itself was, if anything, strengthened.

A probable reason for consolidation was the crisis in tin prices after World War I. The Netherlands had then joined an international effort to limit production, the Bandung Agreement (1921-1924).51 An additional reason may have been the wish to maintain close official supervision of exploitation of natural resources. Although prices recovered during the 1920s, in 1929 the bottom dropped out of the tin market. In the 1930s even more drastic tin reduction schemes took effect (1931-1934, 1934-1936, 1937-1941). ${ }^{52}$

Belitung had become a high-cost tin producer compared to Bangka. Producing tin cost 50 percent more than on Bangka, one of the world's lowest-cost operations. ${ }^{53}$ Reduction schemes would, therefore, threaten its position more than they would the state-run Bankatinwinning, although the world tin price still left a comfortable profit margin for both. Finally, prewar conditions had led to a recovery of tin prices and sales and relief from reduction schemes after 1938. ${ }^{54}$ In 1937, production of tin was 13,500 tons, in 1941, over 20,000 tons. ${ }^{55}$ Whatever the impact on the Company, the effects of the depression on Belitung's population were even more dramatic.

\footnotetext{
48 The Company was also accused of excessive depletion of resources (roofbouzw), see Gedenkboek 1927 vol. 1: 4449, app. 5; and vol. 2: app. 13 show production through 1913. Subsequently, production per man dropped to about half that of Bangka, mostly because Belitung's richer sites had been exhausted.

49 These included duties and monopoly rent for alcohol, opium, slaughtering, and so forth, in addition to the 10 percent of profits required to be turned over to the state by the Company's concession. E. B. Kielstra, "Banka en Billiton," Tijdschrift voor Economische en Sociale Geographie 1 (1910): 352; cf. Gedenkboek 1927 2: 13.

50 According to K. E. Broersma, Eene zaak van regt en billijkheid: Enkele episoden uit de enerverende Billiton-geschiedenis, 1860-1985 (Leidschendam: Billiton International Metals, 1985), p. 20, and ARA MR 2741 1918, p. 1, the original capital was $\mathrm{f} 5,000,000$ divided into 5,000 shares.

51 Kamp, Tinnen soldat, p. 202.

52 Ibid., pp. 204-5.

53 On Belitung in 1937, production costs for one quintal $(100 \mathrm{~kg})$ of tin were 993.41 , as compared to 660.49 on Bangka.

54 Kamp, Tinnen soldat, pp. $282-83$.

55 Allen and Donnithorne, Western Enterprise, p. 170. This source gives 19,000 tons as production for 1941, but according to ARA Rapp. Indon. 544, 23,140 tons of tin-in-ore were exported in 1940 and 22,824 in 1941 . The discrepancy may be owing to a difference between actual production and export caused by selling from stockpiles.
} 


\section{Demographic Trends to World War II}

Table 1. Chinese in Belitung's Population

\begin{tabular}{cccc}
\hline \hline Year & Total Chinese & Percentage of Population & Chinese Women $^{\mathrm{a}}$ \\
\hline 1920 & 28,968 & 42.2 & 1,816 \\
1930 & 28,614 & 39.1 & 6,023 \\
\hline
\end{tabular}

Source: Volkstelling 1920 and 1930.

a Including girls.

The fact that the Chinese population of Belitung had grown to over two-fifths of the total population by 1920 must be seen in relation to the number of mine coolies. Of these 28,968 Chinese, 22,292 were employees of the Company. About 1000 women were among the Billiton group, probably from a few families of miners because women did not work in the mines. ${ }^{56}$ Mineworkers were 77 percent of the ethnic Chinese population. After 1920, however, mine employment began to decline. Both mechanization and depressed prices led to widespread layoffs, proving how temporary and expendable the coolie miners were.

Not surprisingly, in the 1920 census, almost all ethnic Chinese gave Chinese as their daily language; the role of Malay was negligible. ${ }^{57}$ This is in striking contrast to the Chinese in Java, who used Malay and other local languages widely. Most of Belitung's Chinese were immigrants and transients, recently arrived and living in near-isolation from the local population in mining areas.

Yet figures confirm the modest growth of a settled Chinese population on Belitung by 1930: although nearly $20,000(19,736)$ Chinese were foreign-born, of the approximately 9,000 locally born $(8,867), 42$ percent had fathers born in the Indies. The change in sex ratio because the number of women had more than doubled also confirms this. More than twothirds of the Chinese were Hakka. ${ }^{58}$

Belitung's officials believed the majority of the workers ( 60 percent in one estimate) had left wives in China to look after their parents or to care for their property. Most miners expected to return to China, and while they were in Belitung, there was little opportunity for the women to contribute to earnings so it was better for them to remain in the homeland. ${ }^{59}$ The increase in Chinese women and girls between 1920 and 1930 may be partly from immigration of women from elsewhere in the Indies, especially Bangka, as wives of townspeople or better-situated mine employees. Intermarriage with native women was not common. On the other hand, as they began pepper planting and other small-scale agriculture about this time, former miners may have brought women from China to help work the land.

The depression was "calamitous" to the entire island, to cite the economic historian Cator. Even between 1920 and 1930, the Chinese population of Belitung, including miners,

56 See Volkstelling 1920; report of the Labor Inspectorate Arbeidsinspectie 10 (1925): 44.

57 All the above figures from Volkstelling 1920, pp. $206 \mathrm{ff}$.

58 Volkstelling 1930, vol. 7, and Cator, Economic Position, p. 183. Totals may differ slightly.

59 Arbeidsinspectie 15 (1930-1932): 90 . This point is worth emphasizing not only because emigration was part of a socially accepted system affecting certain areas in China, in this case Meixian, but also because miners frequently remitted money to families in China from Belitung. In Bangka, coolies came from a greater variety of geographic origins and from very poor, displaced elements; there, family remittances were not common. 
fell slightly, as did the proportion of Chinese in the population. Reductions affected the numbers of Chinese as the depression deepened after 1930 (see table 2). ${ }^{60}$

Table 2. Effect of Depression on Population and Mine Employment, 1920-1933 (figures rounded)

\begin{tabular}{ccccc}
\hline \hline Year & All Chinese & Chinese Miner & Native & Miner \\
\hline 1920 & 29,000 & 21,000 & 39,000 & 1,500 \\
1930 & 29,000 & 19,000 & 44,000 & 1,200 \\
1932 & 14,000 & 8,000 & 44,000 & 500 \\
1933 & 10,000 & 4,000 & 44,000 & 400 \\
\hline
\end{tabular}

Beginning in 1929, thousands of discharged miners were returned to China at the expense of the Company; other laborers and small traders not in mining employ also left for China or Singapore. By 1932, in addition to discharged miners, perhaps 30 percent of the noncoolie part of the Chinese population had departed. Three thousand more coolies were scheduled to leave that year. ${ }^{61}$

The effects on Belitung's economy were dramatic; former miners now also found the possibility of settling there unattractive. The 1930 census reported, for example, that over five thousand of the nearly eight thousand Chinese engaged in agriculture were foreignborn ( 72 percent), and nearly all of these must have been former miners and their families. In the 1930s, however, even these farmers wanted to leave. It was the local-born who persisted, some still attempting to make a go of it in pepper, 62 a crop that had been moderately successful on Bangka.

The recovery of tin prices at the end of the 1930s meant a slight increase in employment. In 1939, 5,155 Chinese worked for the Company, 4,914 as miners. By this time, over 2,000 natives (including "natives" from other parts of Indonesia) were also employed by the Company. ${ }^{63}$ A postwar source reports that employment climbed to over 6,000 Chinese and 3,400 natives just before war came to the Indies in 1942.64

Replacing Chinese with natives became a possibility only when machines had replaced the physical drudgery of digging, lifting, and carrying. Although in plantation work in East Sumatra Chinese had been phased out in the 1920s, and they made up only 10 percent of the labor force in 1930, 65 mine authorities insisted for years that Indonesians could not stand the

${ }^{60}$ The prior discussion and table are from Cator, Economic Position, p. 181, based on Volkstelling 1930 and official estimates.

61 Memorie van Overgave de Wilde, 1932 (International Documentation Centre, Zug, Switzerland, microfiche), pp. 1-7. This is probably the source for Cator's 1932 estimate of population and some of the information in the following paragraph. Unfortunately, no one knows much of the effects of the repatriation on the societies and economies of home areas in China.

62 Cator, Economic Position, pp. 182-83, 210. Belitung's annual (white) pepper exports in the last prewar years were about 100 tons.

63 GMB Jaarverslag 1939, p. 14.

64 ARA Rapp. Indon. 544. Figures for 1939 in this source differ slightly from those in the Jaarverslag, n. 64.

65 Stoler, Capitalism and Confrontation, p. 30. In the nineteenth century, Chinese had been 90 percent of the labor force. 
hard physical labor required in the mines. The trend toward replacing ethnic Chinese with natives would accelerate after World War II.

\section{The Japanese Interregnum and Its Aftermath}

The upturn accompanying the prewar boom in tin prices was short-lived. Soon the war in Asia reached the Indies.

Before April 10, 1942, when Japanese troops took over the island, some European personnel of the Company and their families were evacuated to Java. The remainder, who stayed behind and attempted to destroy mining equipment, were captured and interned elsewhere; many did not survive the inhuman conditions in these camps. The Japanese, able to restore some machines, turned mining over to a Mitsubishi affiliate, which produced small amounts of tin before the destruction of Japanese shipping made further efforts useless. ${ }^{66}$

The war years were hard, especially for the mineworkers: Company-subsidized rice deliveries disappeared; nutrition and health care suffered. Soon, people had neither regular work nor anything to buy; many townspeople fled to remote areas and homegrown cassava became the staple food.

With their greater role in the labor force and with their increasing national awareness, Belitung's people began to play a greater role in island administration. A few natives entered political and military organizations sponsored by the Japanese. The former demang of West Belitung, Kiai Agus Mohamad Yusuf became vice-assistant resident under the Japanese; a council (Syu Sangi Kai) was appointed for the island. For the Chinese, except for some blackmarketeers and smugglers, the situation was quite grim. In 1943, over twentyeight hundred coolies were shipped to Palembang to labor in the oil fields; few returned. A few thousand others-both Chinese and native-were forced to build an airfield near Tanjungpandan in 1944-45. Within a few months, three hundred died.67

The end of the war was barely made public when, on August 23, 1945, the Japanese abandoned the island, leaving only a handful of carbines with which the police might maintain order. Probably fear of unrest in this uncertain situation led Yusuf-now in office if not in power-to keep news of Indonesia's declaration of independence from the population until October 20. For the small group of young men in paramilitary organizations, it was too late to organize resistance to the return of the Dutch. ${ }^{68}$ Belitung passed to Dutch control without an interregnum of Indonesia merdeka as occurred in parts of Java, Sumatra, and even on Bangka.

In late 1945 , the Dutch were eager to reoccupy economically valuable parts of the archipelago and expected no resistance. Although the British still urged the Dutch to hold back because the situation on Java was tense, a handful of GMB representatives had managed to land a seaplane in Tanjungpandan on October 18, 1945, two days before Yusuf announced Indonesia merdeka. Met by an apparently friendly crowd and cries of "The Company is back," they speedily returned to Java, from where civil and Company officials and a number of troops set off for the island, arriving on October 21, 1945. With the official surrender of the Japanese commander (who had since returned) to these men, Belitung be-

\footnotetext{
66 Abdullah, Bangka Belitung, pp. 189, 220; Kamp, Tinnen soldat, pp. 109-10. A small stockpile of tin was turned over to the Dutch in 1945.

${ }^{67}$ Kamp, Tinnen Soldat, p. 110; Chang, Wulidong, pp. 16-17.

${ }^{68}$ Abdullah, Bangka Belitung, pp. 220-25, 231.
} 
came the first territory to be transferred from the Japanese directly into Dutch hands, without an allied interregnum. The Company was indeed back. ${ }^{69}$

The Dutch soon arrived at a modus vivendi with most local officials, but the young people, pro-Republican elements and Tentara Keamanan Rakyat (TKR) units from Bangka launched attacks on the Dutch at Air Merbau and Selat Nasik in November and December. ${ }^{70}$ Sporadic violence also plagued rural areas; in February 1946, five Chinese were murdered in Air Bara. ${ }^{71}$

As Dutch control was consolidated, two issues became dominant: (1) rehabilitation of the economy, that is, increasing tin production, which was linked above all to the Chinese and their politics; and (2) forming some kind of self-government to counteract that of the Indonesian Republic, a matter of Indonesian politics. In both fields, the Company played a dominant role.

\section{Economic Rehabilitation and Chinese Politics}

The physical task of rehabilitating the mines-repairing and replacing equipment, removing water from the underground mine at Kelapa Kampit-was daunting. The work force had been decimated. European supervisors and technical personnel were brought in, some from internment camps, some from the Netherlands. Thousands of laborers were needed; yet many had died, fallen ill, or had fled the mines to "squat" in rural areas, planting cassava to survive. In addition to money (quickly made useless by inflation), workers were lured with rice, textiles, and other allotments in kind.

In February 1948, a single management was formed for the mines of the Netherlands Indies, the Netherlands Indies Tin Council (Tin-raad). Shortly thereafter, the GMB concession was renewed and the Company was also charged with operating the mines of Bangka for the next five years on a profit-sharing basis. The Bangka arrangement continued until 1953, when the Indonesian government took over mining on that island. ${ }^{72}$

\section{Labor Questions}

Even in prewar times, Chinese laborers on Belitung-partly through the efforts of immigrant schoolteachers-had become more politically active. The 1920 s and early 1930s had seen a number of strikes and other incidents, some violent. ${ }^{73}$ The coolies' experiences during the Japanese occupation and their pride in a resurgent China now made them quick to recognize when Dutch policy opposed their interests. When wages were too low, goods distributed too few, illegal occupants of farmland (ladang) expelled, the Chinese reacted.74

A serious challenge was the strike of Chinese tin miners centered in the Tanjungpandan district, which broke out on April 29, 1946, and provoked military intervention. The miners'

\footnotetext{
69 "De Maatschappij is terug," Kamp, Tinnen soldat, pp. 110-11; Abdullah, Bangka Belitung, pp. 234-39. ARA Rapp. Indon. 544, which also recounts the first landing, says many Chinese flags and a few Dutch ones greeted the GMB delegation on October 18. Fearful of violence and reluctant to take sides openly, many Chinese flew a Chinese Nationalist flag during 1945 to indicate their neutrality in the Dutch-Indonesian conflict.

70 Abdullah, Bangka Belitung, pp. 79-81, ARA Rapp. Indon. 544. The Dutch had about sixty former prisoners of war from Singapore as troops.

71 ARA Rapp. Indon. 539.

72 Kamp, Tinnen soldat, pp. 284-85; Allen and Donnithorne, Western Enterprise, p. 171.

73 See reports in Harry A. Poeze, ed., Politiek-Politioneele Overzichten van Nederlandsch-Indië, 1927-1928 (The Hague: Nijhoff, 1982), 1: 71, 89, 205, 380, 479; and 1929-1930 (1983),2: 47-48; Arbeidsinspectie 15 (1930-1932): 137.

74 ARA Rapp. Indon. 546.
} 
union, Lao Kung Hwee (also spelled Loh Kung Fui) (LKH) (Pinyin, laogonghui, labor association) asked for a raise, a holiday on May 1, and an end to working three shifts around the clock. Their organization was able to obtain some concessions, but several workers were jailed in the struggle and the strike failed to get widespread support. ${ }^{75}$ This strike was a rehearsal for a larger one the following year.

In Belitung on May 3, 1947, all Chinese laborers employed by the GMB (more than three thousand men), who made up about half the total labor force, led by the Lau Kung Chung Hwee (Laogongzonghui, Federation of Labor Associations) struck. This new title shows that several local organizations had united. ${ }^{76}$ Except for a brief work stoppage, the Indonesian labor union, Perkabi (probably an abbreviation for Perkumpulan Kaum Buruh Indonesia), remained aloof from the action, and most Indonesian tin workers stayed on the job. Officials felt the demands of the workers were "absurd," and they blamed professional labor agitators for the trouble-men whose success depended on radicalizing the workers not on helping them. Among organizations that expressed support for the strikers, however, were the Sin Ming Hwee Batavia, Sarekat Organisasi Buruh Seluruh Indonesia (All-Indonesian Federation of Labor Unions [SOBSI]) (the labor federation subsequently associated with the Communist party) and labor groups on Bangka. The Company resorted to Batavia's Department of Social Affairs for help.77

In fact, strikers at one point admitted to the Company that they were taking orders from Java. ${ }^{78}$ The strike ended August 15, 1947, when the Sin Ming Hwee Batavia sent a telegram to the Lao Kung Hwee Tanjungpandan to resume work. Remaining Chinese workersabout 2,500 out of an original 3,340 strikers-then returned to work. The strike had lasted three and one-half months. Figures for average numbers of Company workers from April to November 1947 demonstrate its effectiveness.

Table 3. Mineworkers at Work, April to November 1947

\begin{tabular}{lccccccc}
\hline \hline & April & May & June & July & August & September & November \\
\hline Laborers & 7,028 & 3,461 & 3,494 & 3,885 & 6,271 & 6,687 & 7,028 \\
Administration & 1,624 & 1,484 & 1,324 & 1,073 & 1,139 & 2,008 & 1,243 \\
\hline
\end{tabular}

Yet rehabilitation of the economy suffered only temporarily. During December 1947, the Company employed 9,574 workers and exported, in tin equivalent, 1,042 tons, about twothirds of prewar production. ${ }^{79}$

75 Abdullah, Bangka Belitung, p. 329; ARA Rapp. Indon. 537; Chang, Wulidong, pp. 21-23.

76 Consolidation of the LKH branches into a federation put it in a stronger position than in 1946 when workers in Manggar, a major mining center, had failed to join the strike. Cf. Chang, Wulidong, pp. 22-23.

77 ARA Rapp. Indon. 539. The Sin Ming Hwee was a social organization of Peranakan Chinese in Jakarta established in 1946 with a strong interest in labor questions. See Mary F. Somers Heidhues, "Citizenship and Identity: Ethnic Chinese and the Indonesian Revolution," in Jennifer Cushman and Wang Gungwu, Changing Identities of the Southeast Asian Chinese since World War II (Hong Kong: Hong Kong University Press, 1988), p. 124. At this time, Sin Ming Hwee members represented various political points of view, but little is known of its labor activities.

78 ARA Rapp. Indon. 539.

79 ARA Rapp. Indon. 546. About 1,600 tons per month were exported before the war. Statistics refer to "tin equivalent" because only ore was exported; it was smelted abroad. 
What struck some Indonesian observers, however, was the importance of internal solidarity to the strikers. The Chinese had collected a strike fund, and it helped them hold out longer. Because the Indonesians did not strike, however, the stoppage contributed to the further replacement of Chinese by ethnic Indonesians. ${ }^{80}$ Many strikers now moved elsewhere and about 10 percent found other jobs or other means of support. ${ }^{81}$

In fact, the Company had other means to quell the strike besides substituting ethnic Indonesians for the Chinese workers. The Company could, and did, refuse to accept wives and children of strikers in the (Company) hospital, it stopped providing school transportation for the children, and it repossessed bicycles loaned to workers, among other tactics.82 Workers also depended on rice from the Company, which was not available to strikers. ${ }^{83}$

There were repercussions outside Belitung. The Chinese (Guomindang, Nationalist) consul from Palembang visited Belitung in July 1947 as a result of the strike. ${ }^{84}$ This token of China's renewed interest was welcome, but the consul disappointed the workers when he disapproved of the strike. In Manggar, in the heart of eastern Belitung's mining country, when the chairman of the Chung Hwa Chung Hwee (Zhonghua Zonghui, Federation of Chinese Associations, probably a pro-Guomindang organization) urged strikers to end the walkout, he was shouted down. ${ }^{85}$

A two-year process of rectification among the laborers followed the strike. ${ }^{86}$ Many workers had left the island, and union finances dwindled. Some new union officers were Chinese schoolteachers, known before the war as a highly politicized group. One report calls the LKH "known to be Communist." 87

One lesson of the strike was the importance of Chinese-Indonesian cooperation. In early 1948 , the new chairman of Perkabi, the union of ethnic Indonesian mine workers, was more open to cooperation with LKH. In late April 1949, several Indonesian workers, finding Perkabi too tame for their needs, asked to join LKH. In the end, one hundred Indonesian members were admitted; LKH now accepted the principle of interethnic cooperation. Soon Indonesians were leaving Perkabi for LKH en masse. In November 1949, Perkabi finally changed its name to Partai Buruh Indonesia (PBI), joining the party of the same name in Republican territory. Many members, especially officials, were not laborers. According to a Chineselanguage source, the PBI brought together Chinese and Indonesian workers without destroying their independence, 88 a matter of concern to some Chinese workers who did not wish to be drawn, at that time, into Indonesian politics. The PBI soon contacted SOBSI, but the PBI probably was ideologically more or less socialist. ${ }^{89}$ As an example of interethnic

\footnotetext{
80 ARA Rapp. Indon. 539.

81 Ibid.

82 Translated (from Chinese to Indonesian) letter from the chairman of the Loh Koeng Chung Hwee, Tjhie Tjoen Fong, dated May 17, 1947, in minutes, Provisional Council, typescript, in my possession.

83 Letter from member of East Belitung Council, Manggar, June 27, 1947, in minutes, Provisional Council, typescript, in my possession.

84 Abdullah, Bangka Belitung, p. 329.

85 ARA Rapp. Indon. 539.

${ }^{86}$ Chang, Wulidong, p. 30.

87 ARA Rapp. Indon. 540.

88 Chang, Wulidong, p. 31.

${ }^{89}$ See this opinion in ARA Rapp. Indon. 540.
} 
cooperation in labor affairs, it offered new possibilities: the strikes of 1946 and 1947 had been weakened because while Chinese struck, Indonesians worked.

The establishment of the People's Republic of China in October 1949 filled the LKH leadership with new enthusiasm. The Chinese community as a whole, however, was divided between a relatively small group of older, more conservative pro-Guomindang elements and numbers of young people, students, teachers, and labor union officials, who supported the Chinese Communists. ${ }^{90}$

\section{Indonesian Politics}

When the Dutch persuaded the British to transfer full authority over Indonesia outside Java and Sumatra to them in July 1946, ${ }^{91}$ they immediately began preparing to organize these areas into "self-governing" regions, to be united in a federal state.92 For Belitung, this meant the formation of a provisional Dewan Belitung or council; in 1947, members of the council were formally elected. Although some ethnic Chinese were both electors and members, interest from the Chinese community in federal politics was always small. The Chinese were preoccupied with what was happening in China, and in any case, the council had little authority. The problem of the Dewan Belitung and its relations with the Dutch and the Republic was essentially one of Indonesian politics.

Records show that the council devoted a great deal of effort to organizational matters: elections, prerogatives, and its relations with other federal areas, especially Bangka and Riau. Kiai Mohamad Yusuf, who had served under the Japanese, ${ }^{93}$ became council chairman. Other matters-apart from the ever-present question of independence, the Indonesian Republic, and its symbols-were education and economic rehabilitation.

Nevertheless, an incident at the time of the 1947 strike shows how little authority the council had. In April 1947, the Dutch chairman of the provisional Dewan Belitung (before Yusuf was installed as chairman) informed the members that a "rather large" strike had already broken out among Chinese laborers of the GMB (before the full-fledged strike of May 3). It was "purely a matter between employer and employee." The administration would remain in the background; the provisional council would have nothing at all to say. ${ }^{94}$

Another comment in the council sums up what being a "Company island" meant. When the elected Dewan Belitung met in September 1947, a Dutch official (J. S. Krom) addressed the meeting. Belitung, he reported, was a land of many complaints. The first complaint he mentioned was about the excessive influence of the Company. If the GMB had power over so many things that had nothing to do with tin, such as distribution of light, water, tele-

\footnotetext{
90 ARA Rapp. Indon. 540.

${ }^{91}$ At present, Bangka and Belitung are part of the province of South Sumatra: historically, they were subject to Palembang. However, the Dutch ruled both areas directly from Batavia, and, although during the Revolution some people on the islands supported the idea of being part of Sumatra-and according to the terms of the 1946 Linggajati Agreement, therefore, part of the Indonesian Republic-the Dutch successfully resisted their inclusion in Sumatra until the Transfer of Power. When Federal states were formed, there was talk of a state that would combine Bangka, Belitung, and the archipelago of Riau, but nothing came of it.

92 See, for a brief account, Anthony Reid, The Indonesian National Revolution, 1945-50 (Hawthorn, Australia: Longman, 1974), p. 108.

93 In Belitung and Bangka, many members of the "federal" councils had served under the Japanese. As far as I know, the issue of their collaboration was not raised, as it was with Sukarno and Hatta.

94 Minutes, Provisional Council, Belitung, April 10, 1947 typescript, in my possession.
} 
phones, and so on, it was because the administration and population relied too much on the Company to take care of such matters: "Minta tolong pada GMB."95

Groups outside the council (and a few persons inside it), however, maintained Republican sympathies. Both Islamic and secular-nationalist groups began to organize politically in 1947-48. In May 1947, the Nurul Islam had grown to be an influential association with several hundred members, appealing to the more strongly Islamic elements. In 1948, it became a political association, later affiliating with Masyumi.96

Among youth, the Sarikat Pemuda Indonesia Pulau Timah was a pro-Republican group. Another was PIM. From Persatuan Indonesia Muda it changed its name to Partai Indonesia Muda in late 1948 as pro-nationalist organizations were becoming bolder. PIM took a noncooperative attitude toward Dutch official activities ${ }^{97}$-something difficult to do when the Company and the colonial administration were the island's major employers.

\section{The End of the Company}

With the transfer of sovereignty to Indonesia in 1949, ownership of the five-eighths share in the Company passed to the Indonesian government. The remaining shares were held by the Billiton Mij in the Netherlands. European personnel remained on the island; in the early 1950s, tin prices climbed, but the end of the Korean War brought a renewed fall.

Although Chinese coolies continued to be replaced by ethnic Indonesians, it appears that few European managers were replaced by local people. When in 1958 the Company was dissolved-other Dutch assets in Indonesia were seized by the Indonesian government in connection with the dispute over West Irian-the Indonesians offered to retain the Dutch managers and engineers. Almost to a man, they chose to repatriate. ${ }^{98}$

The Billiton Company returned to Indonesia in 1968 with an offshore tin concession in Pulau Tujuh, small islands between Bangka and Singkep, which has since been liquidated. Bought out by Shell in 1970, the successor to the Company is now Billiton International Metals BV. The firm has interests in tin mining but not in Indonesia. ${ }^{99}$

\section{Conclusion}

Bangka's tin was never, not in the sultan's time, not in the English period, not under the Dutch or the Indonesians, opened to private Western enterprise. ${ }^{100}$ Billiton was a Company island from the start to 1958-with the provision, of course, that the Company was, by majority, government-owned after 1923. Now an Indonesian government-owned company (PT Tambang Timah) runs the mines on both islands, although smaller concessions are leased to foreign private enterprise.

Besides opening tin mining, the Company also brought tens of thousands of Chinese laborers to the island. Belitung's ethnic Chinese element today is far less than it was in 1920 or $1930(29,000)$. In 1979, the population of Belitung was 150,130: 15,091 were alien Chinese;

\footnotetext{
95 Ibid.

96 ARA Rapp. Indon. 540.

97 ARA Rapp. Indon. 539, 540.

${ }^{98}$ Kamp, Tinnen soldat, pp. 284-85. The number of Europeans working on Belitung for the GMB, 165, was according to my information about the same in 1958 as it was in the 1920 s. Cf. Broersma, Enkele episoden, p. 74.

${ }^{99}$ Broersma, Enkele episoden, pp. 74, 76ff; Abdullah, Bangka Belitung, 190.

${ }^{100}$ One small exception: near Koba, Koba Tin is presently a joint Indonesian-Australian enterprise.
} 
2,984 were citizens of non-Indonesian origin-with few exceptions, ethnic Chinese. Only 12 percent of the population were Chinese, and 83 percent of the Chinese were aliens. ${ }^{101}$

Since 1979, the proportion of Chinese has remained steady, but most Chinese have become citizens. In 1984, the island population comprised 173,604 persons. A mere 1,851 were alien Chinese; 19,353 were Indonesian citizens of Chinese origin. This means, again, that 12 percent of the population were ethnic Chinese, but 91 percent of the Chinese were citizens. ${ }^{102}$

The Company no longer dominates Belitung, and the Chinese have lost their numerical importance, but tin continues to rule the economy. In 1978, Unit Pertambangan Timah Belitung, the Belitung unit of the government tin concern, employed over twelve thousand persons with an estimated forty-one thousand dependents, which together equaled more than one-third of the island's population. ${ }^{103}$ When persons in auxiliary occupations are added, as well as those working in the private concession in Kelapa Kampit (now exploited by Preussag, a West German firm), the dominance of tin in the economy is obvious.

The present-day visitor to Belitung finds numerous relics of Company history, some preserved in a small museum. The former clubhouse or Societeit still functions as a meetinghall. It was once the family home of Ho A Joen, Kapitan Cina, coolie trader, and opium farmer in early mining days. The Ho family altar remains preserved in the building. ${ }^{104}$

Unfortunately for the island, depressed tin prices have led to cutbacks and the transfer of production elsewhere in recent years. Other efforts to diversify the economy-kaolin and ceramics, pepper, lumber, tourism (the island has a fine beach near Tanjungpandan)-have remained on a small scale. A new wrinkle in Belitung is the opening of some transmigration projects in the sparsely settled south of the island. The economic effects of that effort remain to be seen.

Being a Company island brought some benefits-roads, telephones, early health services, education, electricity-to many people of Belitung; some benefits remain. Private, capitalist enterprise, with the exception of the Kelapa Kampit concession, came and went. By the time Belitung was no longer a Company island, most of the benefits had been transferred elsewhere.

101 Kabupaten Belitung dalam angka 1978 (Tanjungpandan, Kantor Statistik Kab. Belitung, 1979), p. 24.

102 Kabupaten Belitung dalam angka 1984 (Tanjungpandan, Kantor Statistik Kab. Belitung, 1985), pp. $12,17$.

103 Kabupaten Belitung dalam angka 1978, pp. 24, 55.

104 For a full-page photograph of the altar, see Gedenkboek 1927 2: 147. The family were Hakka from Huizhou, Guangdong; see Phang Tjap Hie, "De Tepékong in de Sociëteit te Tandjong-Pandan," Erts, (Billiton-Nummer), (July 1951): 170. Ho is probably identical with He Zhaoxiang (or conceivably, because the syllable "Joen" is identical with "Yun," with his brother He Zhaoyun). Franke, Epigraphic Materials, pp. 517-19, describes and translates tombstones in the Ho family cemetery near Tanjungpandan, but he does not identify individuals in their Indonesian context. 